\title{
Research Article: An analysis mechanical Vs conventional method of sugarcane cultivation in Latur district
}

\author{
T.B. MUNDE, V. P. WAVDHANE AND S.C. NADARGE
}

Article Chronicle : Received : 11.07.2017;

Accepted :

26.07.2017

\section{Key Words :}

Sugarcane,

Mechanical method, Conventional method, Cost of cultivation
SUMMARY : Sugarcane (Saccharamofficinaram) belongs to family gramineae and is one of the major commercial crops of India. Maharashtra having second position in area and production of sugarcane with 0.78 million hectares and 57.80 million tonnes, respectively. Maharashtra having fourth position with 74.10 tonnes per ha. Latur is among one of the major district of Maharashtra where sugarcane is cultivated on an area of 0.024 million hectares area sugarcane production is 1.84 million tonnes and productivity is 77.00 tonnes per hectare. The study was centered on the analysis economics mechanical vs conventional method of sugarcane. The study will be useful for the farmer in minimizing the cost and increasing the profit. Multistage sampling design was adopted in selection of district,villages and sugarcane growers. The analytical techniques liketabular analysis in which arithmetic mean with cost concept cost-A, cost-B, cost-C and percentage and cost-benefit ratio. Investment on commonly used assets and irrigation structure was Rs.4726.92 and Rs. 82834.76 on the mechanical method of sugarcane farm while it was Rs. 4288.67and Rs. 80543.75 in conventional method of sugarcane farm observed. Gross return was found to be Rs. 283874.00, Cost-C was Rs. 149592.12 and net profit was Rs. 134281.88 in mechanical method of sugarcane farm, while in conventional method of sugarcane farmit was Rs. 254127, Rs. 151628.93 and Rs. 102498.57, respectively. Per tones cost of production of sugarcane was higher as Rs. 1448.50 in conventional method as compare to Rs. 1219.17 in mechanical method of sugarcane farm. The output-input ratios were 1.90 and 1.68 in mechanical method and conventional method of sugarcane production.

How to cite this article : Munde, T.B., Wavdhane, V.P. and Nadarge, S.C. (2017). An analysis mechanical Vs conventional method of sugarcane cultivation in Latur district. Agric. Update, 12 (TECHSEAR-4): 983-989; DOI: 10.15740/HAS/AU/12.TECHSEAR (4)2017/983-989.
Author for correspondence :

\section{T.B. MUNDE}

Department of

Agricultural Economics and Statistics, PGI, Dr. Panjabrao Deshmukh

Krishi Vidyapeeth, AKOLA (M.S.) INDIA Email:tukarammunde01 @ gmail.com

See end of the article for authors' affiliations 